\title{
A method for yield assessment on rainfed dryland agricultural fields
}

\author{
Alexander Groengroeft, Jona Luther-Mosebach, Lars Landschreiber \& Benjamin \\ Kowalski
}

\begin{abstract}
River flow and inundation of floodplains support a variety of ecosystem services in the Okavango Delta in Botswana. However, river channel desiccation occurs for a number of years or permanently, resulting in adverse impacts on ecosystem services-dependent livelihood activities. This phenomenon is caused by changes in rainfall patterns as well as by shifts in flow distribution due to a number of factors. This study has investigated the relationship between adaptation to desiccation and ecosystem services which support livelihoods in the Okavango Delta. Research methods included the use of aerial photographs and satellite images, household survey, focus group discussions, hydrological modelling and the construction of scenarios on socio-economic impacts of desiccation. The results of the study showed that desiccation adversely affects various livelihood activities, particularly those based on ecosystem services such as flood recession agriculture, livestock farming and veld products collection. It is further revealed that this phenomenon is likely to increase in frequency and intensity in the future as a result of climate change. The paper posits that adaptation policies which support diversification of livelihood activities into those which are less dependent on ecosystem services should be promoted.Within the Okavango catchment, subsistence agriculture is the predominant land use and the main livelihood activity of roughly 86.500 persons. However, knowledge about smallholder crop yields on the local level is sparse or missing but will be of high importance in manifold ways within the TFO-Project as central tasks are multidisciplinary research on soil fertility (soil sciences and economics), evaluation of conservation agriculture methods, calculation of net primary production for carbon balance calculations and incorporation in future land use scenarios. A specific method for yield assessment has been elaborated and tested. Sampling took place during the harvest season of April and Mai 2012 on 26 smallholderowned fields in the Mashare region in northern Namibia on dryland agricultural fields. On a homogeneous part of a field (=sampling area) regarding land use history, sowing date and fertilizer use, the distance between two diagonal opposite corners was measured and five plots of $2 \mathrm{~m} \times 2 \mathrm{~m}$ size were evenly distributed along that line. All plants on each plot were sampled and after drying the yield and plants biomass were measured. A direct and an indirect method for the quantification of grain yield were compared. Results show, that on all fields the main crop was pearl millet (Pennisetum glaucum). The mean dry biomass was $1.46 \pm 0.86 \mathrm{Mg} \mathrm{ha}^{-1}$. From 19 fields where no crops were harvested at the moment of sampling, direct measured mean yield was $161 \pm 76 \mathrm{~kg} \mathrm{ha}^{-1}$. From the dry biomass of cobs calculated data resulted in a mean yield of $155 \pm 122 \mathrm{~kg} \mathrm{ha}^{-1}$. Neither field age nor landscape unit and thus nutritional status did have an influence on the amounts of yields. A possible explanation for that is that the influence of spatially high variable rainfall can overshadow all other factors. However the yield values are in line with findings from the literature for dryland agriculture fields.
\end{abstract}

Keywords: Kavango; Okavango; pearl millet; semi-arid region; southern Africa; subsistence farming.

Um método para a avaliação de rendimento em campos agrícolas de sequeiro

Resumo: Dentro da bacia do Okavango, a agricultura de subsistência é o uso predominante da terra e a principal atividade de aproximadamente 86.500 pessoas. No entanto, o conhecimento sobre o rendimento das culturas de pequenos agricultores, em nível local, é escasso ou inexistente, mas será de grande importância de diversas formas dentro do projeto TFO, visto que as principais tarefas são a pesquisa multidisciplinar sobre a fertilidade do solo (ciências do solo e economia), a avaliação dos métodos de agricultura de conservação, o cálculo da rede de produção primária para o cálculo do balanço de carbono e a incorporação em futuros cenários de uso do solo. Um método específico para a avaliação de rendimento foi elaborado e testado. A amostragem ocorreu durante a época da colheita de abril e maio de 2012, em 26 campos de propriedade de pequenos agricultores na região do Mashare, norte da Namíbia, em campos agrícolas de sequeiro. Em uma parte homogênea de um campo (= área de amostragem), com relação ao histórico do uso do solo, à data da semeadura, ao uso de fertilizantes e à distância entre dois cantos diagonais opostos foram mensurados e cinco parcelas de $2 \mathrm{~m} \times 2 \mathrm{~m}$ foram distribuídas uniformemente ao longo dessa linha. Todas as plantas de cada parcela foram utilizadas como amostras e após a secagem seu rendimento e biomassa foram mensurados. Foram comparados métodos direto e indireto para a quantificação da produção agrícola de grãos. Os resultados mostram que em todos os campos a cultura principal foi o milheto (Pennisetum glaucum). A biomassa seca média foi de $1,46 \pm$ $0,86 \mathrm{Mg} \mathrm{ha}^{-1}$. Dos 19 campos onde as lavouras não foram colhidas no momento da amostragem, o rendimento médio direto medido foi de $161 \pm 76 \mathrm{~kg}$ $\mathrm{ha}^{-1}$. A partir da biomassa seca de espigas, dados calculados resultaram em uma produtividade média de $155 \pm 122 \mathrm{~kg}$ ha ${ }^{-1}$. Nem a idade, nem a unidade de paisagem e, portanto, o estado nutricional, teve influência sobre as quantidades de produção. Uma possível explicação para isso é que a influência espacialmente alta de pluviosidade variável pode ofuscar todos os outros fatores. No entanto, os valores de rendimento estão em conformidade com os resultados da literatura para os campos de agricultura de sequeiro.

Palavras-chave: África Austral; agricultura de subsistência; milheto; Kavango; Okavango, região semiárida.

Received: 16 October 2013 - Accepted: 21 December 2013 


\section{Introduction}

Within the Okavango catchment, subsistence agriculture is the predominant land use and the main livelihood activity of roughly 86.500 persons (estimation based on average household sizes and population density; see Mendelsohn \& ElObeid 2004). Agricultural land use, although being of low productivity, plays a dominant role in providing the rural communities with cereals and thus supporting food security (Mendelsohn 2006). The staple crops of the region change from maize (Zea mays) and cassava (Manihot esculenta) in the Angolan highlands, maize in the middle reaches and pearl millet (Pennisetum glaucum) in the Namibian Kavango to maize, sorghum (Sorghum sp.) and pearl millet in Ngamiland, Botswana.

In the past, the smallholder farming systems in Namibia and Botswana were typically characterized by low population density. This allowed for both the use of long fallow periods as well as the regular shifting of the field locations into formerly unused forest areas. Under these circumstances, such typical practices of soil fertility management can be seen as sustainable and sufficient (see Boserup 1965, Ruthenberg 1971). This situation can still be found in large parts of the southern Angolan highlands. However, due to rising land scarcity caused by an increasing population density, but also due to the growing importance of the cash economy and thus of cash cropping, the historical farming system of Namibia and Botswana has undergone a change (Matlon 1990). Lack of accessible land and reduced or abolished fallow periods have led to an overuse of the agricultural areas. This situation has resulted in increasing soil degradation and an overall reduction of crop yields.

Knowledge about smallholder crop yields on the level of the individual farmer is sparse or missing. From a literature review, Mendelsohn \& ElObeid (2004) reported mean yields for maize in Angola as 500 to $700 \mathrm{~kg} \mathrm{ha}^{-1}$ and in the Kavango and Ngamiland as 100 to $160 \mathrm{~kg}$ $\mathrm{ha}^{-1}$. For pearl millet, the variation seems to be not that strong: the authors report about $250 \mathrm{~kg} \mathrm{ha}^{-1}$ for Angola and 100 to $150 \mathrm{~kg} \mathrm{ha}^{-1}$ for Kavango and Ngamiland. Based on an annual agricultural census Mendelsohn (2006) report average yields for the Namibian Kavango of about 300 $\mathrm{kg} \mathrm{ha}^{-1}$ pearl millet, $550 \mathrm{~kg} \mathrm{ha}^{-1}$ sorghum and $300 \mathrm{~kg} \mathrm{ha}^{-1}$ for maize. As crop yields are affected by various biophysical as well as socio-economical parameters, the transfer of generalized data across space and time (like those given in Landon (1991) mean yields for all less developed countries for millet 1970 - 1972: $590 \mathrm{~kg}$ $\mathrm{ha}^{-1}$ ) is insecure. For research projects with regional to local focus a detailed estimation of crop yields is required to get reliable and comprehensive data. However, depending on the research question the type and intensity of yield assessment has to be chosen carefully. Dumanski \& Onofrei (1989) reviewed the different sources of yield data. They concluded that in many cases observed yields are estimates from farmers, extension officers or field agronomists and only rarely measured under sound scientific programs. Yield data can be produced from weight measurements as well as from crop models. The advantage of direct measurement lies in the fact that there is a dependency on the site specific conditions (such as soil properties; Stein, Brouwer \& Bouma 1997); seasonal weather and the management practice of the individual farmer can be regarded. To quantify the ecosystem service (ESS) crop growth, robust knowledge about annual yields is a prerequisite. For instance Kroeger \& Casey (2007) state, "of course, the total value of ecosystem service for crops also depends on the total quantity of respective crops harvested in the location."

Empirically quantified yield data are important for scientific research in manifold ways: multidisciplinary research on soil fertility (soil sciences and economics), evaluation of conservation agriculture methods, calculation of net primary production for carbon balance calculations and incorporation in future land use scenarios. However, an empirical yield assessment is not only time consuming, but also faces various site specific challenges. In the case of The Future Okavango's (TFO) research area, these factors include:

- There may be a strong microvariability within the fields coming from natural conditions, e.g. former or current termite activities, which has been reported by Chikuvire, Mpepereki \& Foti (2007) for Zimbabwe. Due to the occurrence of former termite mounds in parts of the landscape this effect is likely to be important also in the Okavango catchment.

- Management practice has a strong impact on the distribution of crops on the field and on the time of potential harvesting. The strong dependency of crop growth and ripening on the asset endowment of the household and thus the time of planting leads to significant differences in the potential harvest time between neighboring fields. For the Kavango region, Mendelsohn \& ElObeid (2004) report a millet and sorghum harvesting period from the start of April to mid-July, which is influenced by the seasonal weather situation and also on farmer preferences and needs.

- Depending on farmer needs it is possible that at the moment of assessment part of the field has already been harvested.

- The arable crops are of high importance for the local farmers in securing the families basic food supply throughout the year and also as a source of cash income. Furthermore, the main harvest of the primary crop is often complemented by intercropping with secondary crops, such as beans, cowpeas, groundnuts and melon.

The aim of this study is to test a simple method for empirically measuring yield and biomass and to gain explanatory insights into the variability of yields.

\section{Methods}

To be able to conduct a systematic assessment of crop yields in the Okavango basin, a specific method has been elaborated by the TFO-project. As the assessments concentrate on the amount of biomass and grains on the field at the moment of potential harvesting, yield was defined here as the amount of grains which can be harvested from one field at the end of the growing season. This amount might differ from what was actually harvested by the farmer, as by late harvesting a reduction of grains by birds or other influences is possible. The previously mentioned characteristics of farming in the research area resulted in the formulation of the following objectives for the specification of the yield assessment method: 
$\AA^{N}$

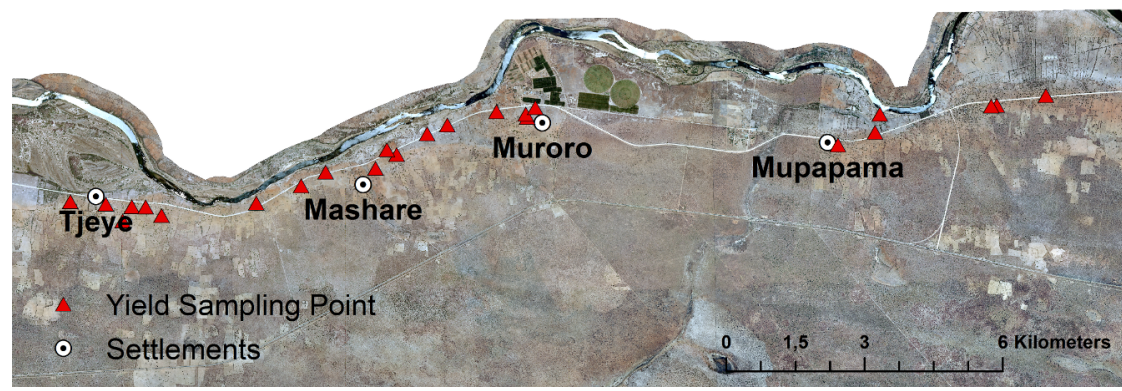

Fig. 1: Fields selected for yield assessments 2012 in the Mashare area. Background Map: Ariel Photograph. Ministry for Lands and Resettlement, Windhoek 2007.

- Bio-physical as well as management-related spatial variability within a field is accounted for by defining sampling areas in cooperation with the farmers.

- The method has to be easy to apply so that the work can be conducted by trained local staff, thus allowing the yield assessment to be conducted throughout the whole harvesting season.

- Harvesting has to be conducted in a reproducible way. This factor requires that each step of the assessment should be done by trained local staff and independently from field owners.

- Assessments include the quantification of the plant biomass to evaluate the relationship between total plant biomass and yields.

- To compensate for harvest losses due to the yield assessment and to acknowledge the help of the local farmer, a small and consistent compensation is handed over to all participants of the survey.

\section{Study site, field selection and sampling area}

Sampling took place during the harvest season of April and Mai 2012 on 26 smallholder-owned pearl millet fields in the semi-arid Mashare region in northern Namibia on rainfed dryland agricultural fields. Locations of sampling are given in Figure 1. For detailed information on the study site refer to fact sheets for the landscape (Groengroeft et al. 2013), climate (Weber 2013), vegetation (de
Cauwer 2013) and soils (Groengroeft et al. 2013) of the Mashare core site. Sampling focused on the intensively used areas in direct vicinity of the river, on the main landscape units Old Floodplains and Kalahari Dune Area and the Transition Zone in between. Soils in these units differ according to their chemical and physical properties. Fertility is in general higher on the Old Floodplains, decreases along the Transition Zone and is lowest in Kalahari Dune Area (see Groengroeft et al. 2013).

Fields were selected by a stratification based on soil characteristics and landscape to account for the environmental variability. The following criteria were applied for the selection of sampling area:

- Same planting week of crops

- Same crop mixture over the

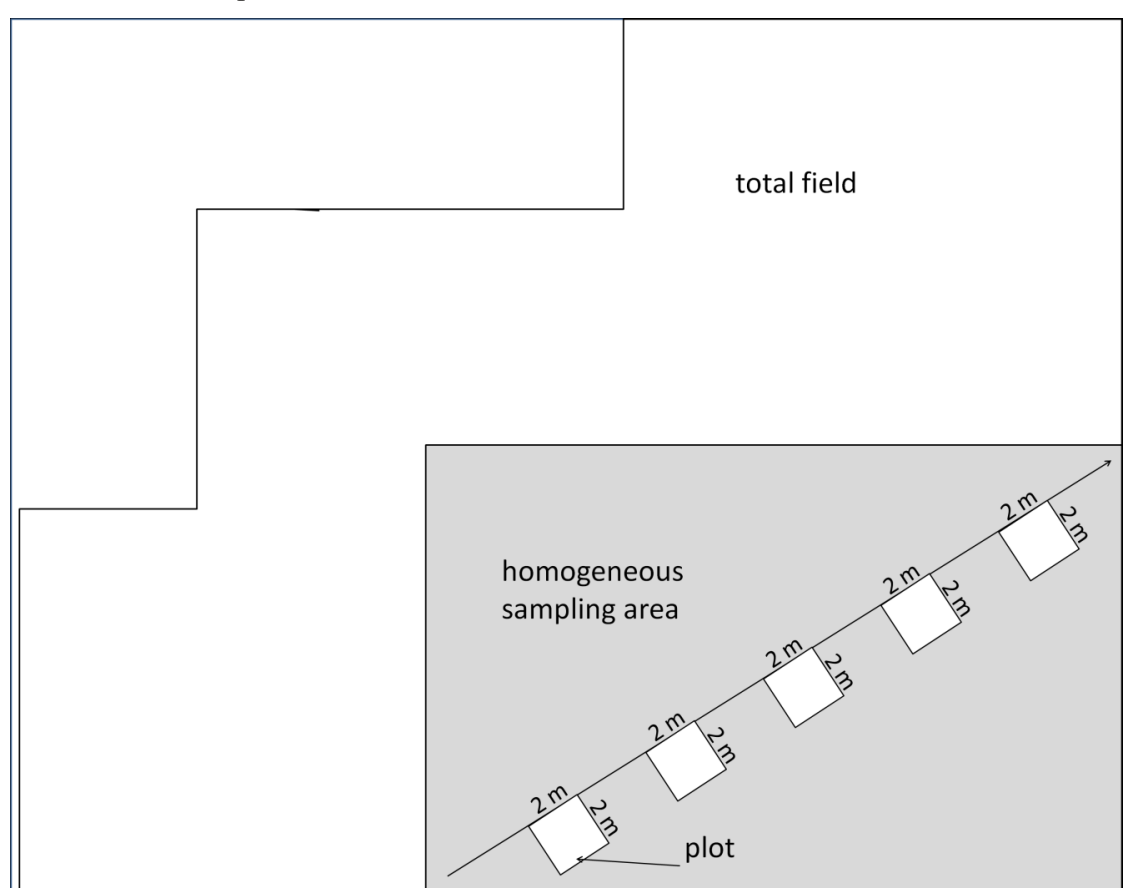

Fig. 2: Design of assessment: plot line on homogeneous sampling area of the total field. entire sampling area

- Homogeneous (if any) application of manure and/or chemical fertilizers

- Same land use history, especially in regard to fallow use, inputs and type of ploughing for the time people remember (manual vs. traditional plough vs. mould board plough)

The field characteristics were evaluated by means of semi-structured interviews with the field owner. Questions included field history (with regard to establishment, inputs of fertilizer and manure, management practices such as duration of fallow use and plowing technique), recent crop production activities (planting date, crop mixtures), quality of soil (subjectively judged by the field owner), recent problems in crop production on assessed field (e.g. pests, wildlife damages) and amount of already harvested crops (if possible in \% of total yield). The criteria led to sampling areas which were often just a fraction of the total fields (Fig. 2).

\section{Sampling}

On the selected part of the fields (=sampling area), the distance between two diagonally opposite corners was measured and five plots of $2 \mathrm{~m} \times 2 \mathrm{~m}$ size were evenly distributed along that line (Fig. 2). GPS coordinates were taken 


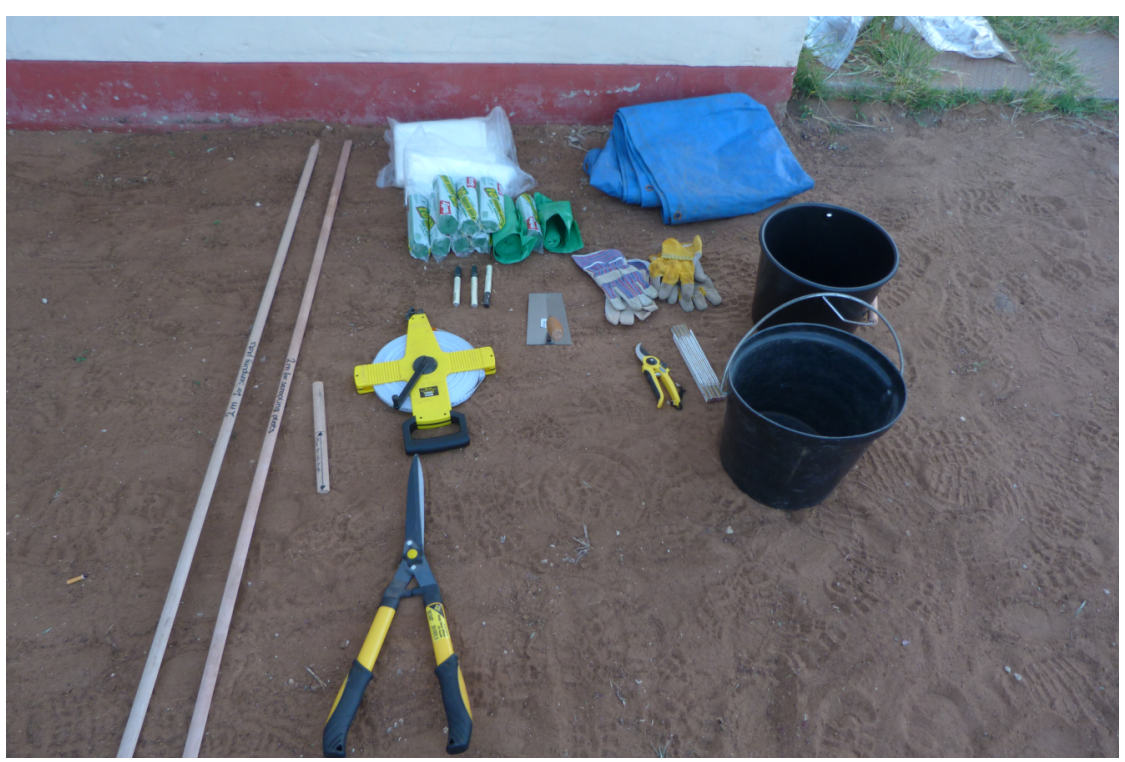

Fig. 3: Sampling equipment: assessment form, pencil, GPS device, AA batteries for GPS, 2 sticks $2 \mathrm{~m}$ for marking the sampling plot, 1 stick $30 \mathrm{~cm}$, plastic bags (zip log and big bag), permanent marker, hedge and garden scissors, $100 \mathrm{~m}$ measuring tape, working gloves, buckets.

from the center of the first and the fifth plot. Every crop plant rooting within the 4 $\mathrm{m}^{2}$-plot was part of the sample. However, in the case of beans all shoots were counted which were within the sampled plot. Each plant, stalk and cob was counted per plot separately for each crop type. The equipment for the sampling is given in Figure 3. The quality of cobs was visually rated in condition classes on an ordinal scale from 1 (very bad) to 9 (very good) by informed and expert opinion.

All plant biomass, separated by crop type, was harvested from each plot and fresh weight was determined. Samples were dried in the sun in ventilated plastic bags. After drying the plant material to constant weight, the dry weight of the biomass (stalks and leaves), the cobs and grains from the cobs were measured separately and individually for all plots. This weighing was performed by using a spring scale and a top pan scale for grains and cobs.

\section{Data analysis}

The dry biomass of pearl millet per $4 \mathrm{~m}^{2}$ plot was calculated by the addition of dry weight of cobs and the dry weight of stalks and leaves. The biomass of all five plots per sampling area was summed up and extrapolated to one hectare. To test a possible future simplification of the sampling procedure, the direct weighing of dried grains from each plot as a of the 26) were ploughed by oxen, only one was hand-hoed. Most of the farmers planted in December (12) followed by January (7). Only a few had already planted in November (3) or planned to do so much later in February (4).

\section{Biomass}

The mean water content of the biomass was $60 \pm 14 \%$ by dry weight. The mean pearl millet biomass calculated from the five plots per field was $1.46 \pm 0.86 \mathrm{Mg}$ $\mathrm{ha}^{-1}$. Values ranged from 0 to $8.5 \mathrm{Mg} \mathrm{ha}^{-1}$ dry weight with a strongly skewed distribution (Fig. 4), with the highest values measured on field \# 4 and \#5 (Table 1). The measured biomass on the individual fields ranged from 0 to 3.72 $\mathrm{Mg} \mathrm{ha}^{-1}$.

\section{Yield}

For all 26 fields, the main crop was pearl millet. Therefore yields are given as grain weight of pearl millet per hectare. Secondary and tertiary crops varied between cowpeas (Vigna unguiculata) (6 times), sorghum (5) groundnuts (Vigna subterranea) (2) and maize (1). This data are not included in the calculation of total yield. These findings could be affirmed by TFO's socio-economic baseline survey, which covered a total of 518 households in the core site and which revealed that millet, maize, beans and groundnuts are the most important crops, both for subsistence production and cash income generation.

No correlation was found between estimated mean cob condition and yield. In total, on 130 plots the cob condition was evaluated of which 14 had no cobs on the plants (i.e., quality condition 0 ), 37 $\%$ got condition $1,22 \%$ condition 2,16 $\%$ condition $3,7 \%$ condition 4 and some very few plots condition 5 to 8 .

A rough estimate of already harvested grains is given in five cases (Table 1). The proportion of harvested crop before

\section{Results}

\section{Land-use management}

The farmer interviews revealed that none of the farmers applied chemical fertilizers and just one used manure. The period of the field use ranged from one year to 45 years with a mean of $19 \pm 14$ years. In three cases, intermediate fallow periods had been indicated. Nearly all fields ( 25

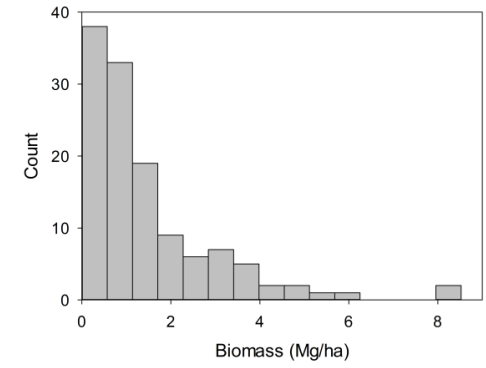

Fig. 4: Histogram of total pearl millet biomass measured at $5 \times 26$ plots. 
Table 1: Results of yield assessment (only main crop = grain of pearl millet). Proportion of yield before assessment is not considered. Fields with unclear proportion of pre assessment harvesting are shaded. All fields with unclear proportion of harvest before assessment are excluded from the calculation of mean values and standard deviations (SD). The values of field 8 are doubled because of the $\mathbf{5 0} \%$ pre-assessment harvested yield. TZ = Transition Zone; KDA = Kalahari Dune Area; OF = Old Floodplain.

\begin{tabular}{|c|c|c|c|c|c|c|c|}
\hline Field Nr. & $\begin{array}{l}\text { Landscape } \\
\text { unit }\end{array}$ & Age class & $\begin{array}{l}\text { First year of } \\
\text { cultivation }\end{array}$ & $\begin{array}{c}\text { Yield harvested } \\
\text { before } \\
\text { assessment }\end{array}$ & $\begin{array}{c}\text { Yield per ha } \\
\text { (kg) }\end{array}$ & $\begin{array}{l}\text { Yield per ha } \\
\text { (kg) calculated } \\
\text { from dry cobs }\end{array}$ & $\begin{array}{l}\text { Dry biomass } \\
\quad\left(\mathrm{kg} \mathrm{ha}^{-1}\right)\end{array}$ \\
\hline 1 & $\mathrm{TZ}$ & A & 1984 & no & 182.0 & 160.1 & 1.59 \\
\hline 2 & $\mathrm{KDA}$ & C & 2006 & no & 33.5 & 30.0 & 0.96 \\
\hline 3 & $\mathrm{KDA}$ & C & 2004 & unknown & 215.0 & 4.4 & 0.45 \\
\hline 4 & $\mathrm{KDA}$ & C & 2007 & no & 136.0 & 37.1 & 3.07 \\
\hline 5 & $\mathrm{TZ}$ & A & 1977 & no & 222.0 & 120.2 & 2.44 \\
\hline 6 & OF & A & 1980 & no & 196.5 & 83.1 & 0.70 \\
\hline 7 & $\mathrm{TZ}$ & C & 2009 & no & 214.0 & 114.1 & 1.66 \\
\hline 8 & OF & A & 1972 & $\begin{array}{l}50 \% \text { five bags } \\
\text { of cobs }\end{array}$ & 267.0 & 545.6 & 2.55 \\
\hline 9 & OF & B & 1996 & $\begin{array}{l}50 \mathrm{~kg} \text { of } 5 \text { bags } \\
\text { of cobs }\end{array}$ & 96.0 & 86.9 & 1.66 \\
\hline 10 & $\mathrm{TZ}$ & A & 1969 & no & 188.0 & 118.8 & 0.91 \\
\hline 11 & $\mathrm{TZ}$ & C & 2006 & $2 \times 50 \mathrm{~kg}$ cobs & 235.5 & 59.4 & 1.09 \\
\hline 12 & $\mathrm{TZ}$ & A & 1967 & $2 \times 50 \mathrm{~kg}$ cobs & 79.0 & 62.2 & 0.56 \\
\hline 13 & KDA & C & 1998 & $\begin{array}{l}7 \text { bags of cobs a } \\
50 \mathrm{~kg}\end{array}$ & & & \\
\hline 14 & $\mathrm{TZ}$ & B & 1987 & unknown & 67.5 & 16.5 & 0.82 \\
\hline 15 & OF & $\mathrm{C}$ & 2005 & no & 103.0 & 92.1 & 1.02 \\
\hline 16 & OF & B & 1985 & no & 124.0 & 168.9 & 1.47 \\
\hline 17 & OF & B & 1988 & no & 112.5 & 110.8 & 1.51 \\
\hline 18 & OF & B & 1989 & no & 229.5 & 259.1 & 3.72 \\
\hline 19 & $\mathrm{TZ}$ & C & 2004 & no & 45.0 & 42.6 & 0.35 \\
\hline 20 & $\mathrm{TZ}$ & $\mathrm{C}$ & 2009 & no & 300.5 & 271.4 & 2.09 \\
\hline 21 & $\mathrm{TZ}$ & A & 1980 & no & 222.0 & 208.2 & 1.43 \\
\hline 22 & $\mathrm{TZ}$ & C & 2011 & no & 219.5 & 245.0 & 2.45 \\
\hline 23 & OF & B & 1986 & no & 108.0 & 113.9 & 0.74 \\
\hline 24 & KDA & unknown & unknown & unknown & 77.0 & 64.9 & 1.62 \\
\hline 25 & OF & C & 2001 & no & 73.0 & 108.1 & 1.26 \\
\hline 26 & $\mathrm{TZ}$ & B & 1985 & no & 86.5 & 72.3 & 0.44 \\
\hline Mean & & & & & 161.2 & 154.8 & 1.46 \\
\hline $\begin{array}{l}\text { Standard } \\
\text { deviation }\end{array}$ & & & & & 76.4 & 122.6 & 0.86 \\
\hline
\end{tabular}




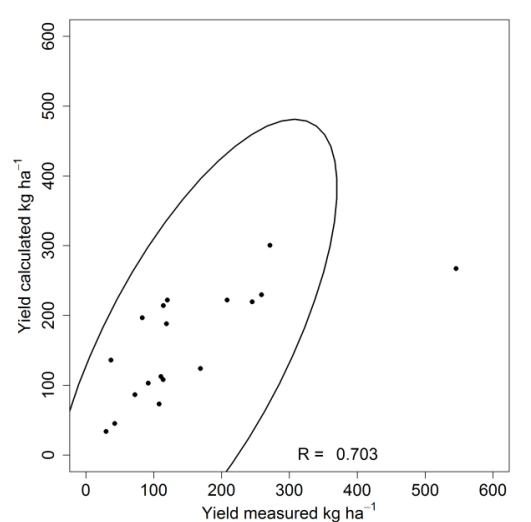

Fig. 5: Relation between total yield measured and total yield calculated from dry cobs per field. Ellipse indicates the $95 \%$ confidence ellipse. Data with unclear proportion of harvested yield before assessment are excluded (Table 1).

assessment is excluded from the calculation of total yield because this information was not spatially explicit.

The results of the yield assessment for each field are given in Table 1. The yield varied between 33.5 and $300.5 \mathrm{~kg} \mathrm{ha}^{-1}$. Both the minimum and maximum yield were analyzed on fields where no harvesting took place before assessment. From 18 fields where no crops were already harvested at the moment of sampling (not shaded in Table 1), the measured mean yield was $155.3 \pm 74.0 \mathrm{~kg} \mathrm{ha}^{-1}$.

Between measured yield data and yield calculated from the dry cob a significant correlation is obvious (Fig. 5), however the error ( $\mathrm{rmse}=85.5$ ) is still relatively high and the calculated method is biased low relative to the measured data.

The pearl millet yield correlates to its biomass $(=$ cobs + stalks $)$ of the fields $(\mathrm{r}=$ $0.598, \mathrm{p}=0.009)$ see Figure 6 , however the scatter plot indicates a strong variation of grain yield with identical biomass.

The yield as well as the biomass production is not clearly related to the general soil nutrient gradient which can be observed with Old Floodplains > Transition Zone $>$ Kalahari Dune Area, however one field on the Kalahari Dune Area indicates that although the biomass production is in the upper third, the yield was relatively small while the second field of that unit had both low biomass and low yield. Between the age of the field and amount of yield no correlation was found (data not shown). Instead, the age of the field was subdivided in three age classes of the same size $(\mathrm{A}-\mathrm{C})$ and

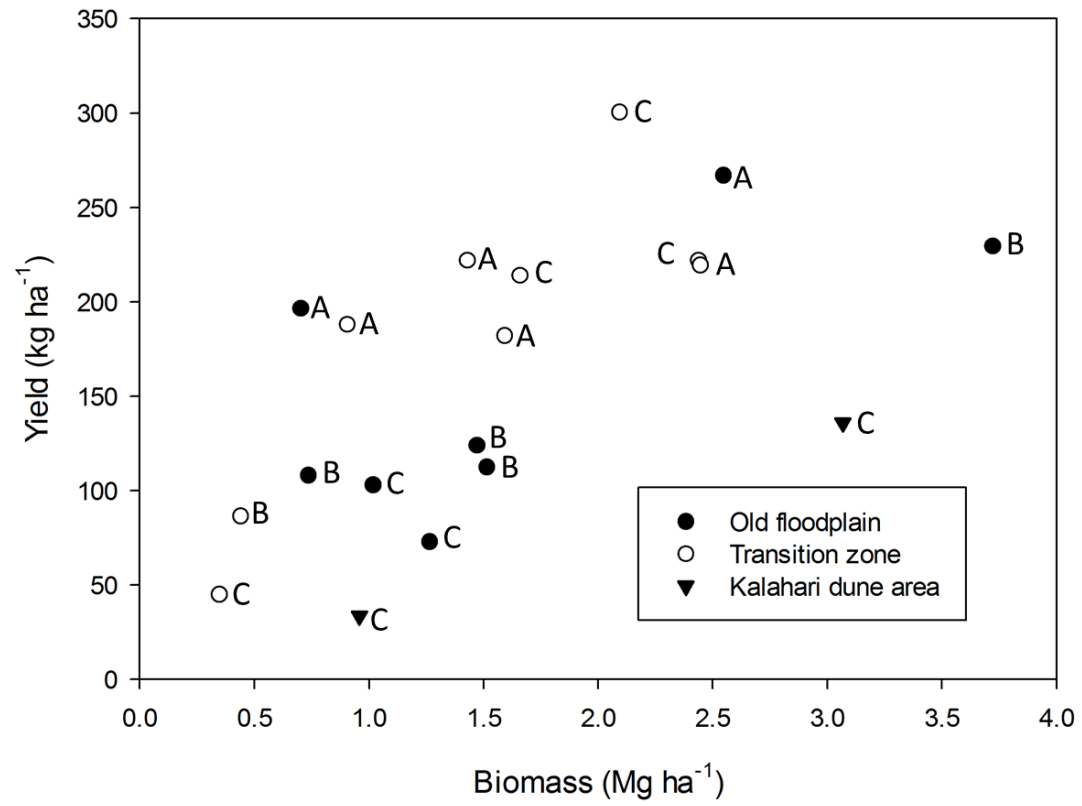

Fig. 6: Relation between mean dry biomass production and total yield (measured) per field with indication of age class (definition: class $A=1967-1981 ; B=1982$. 1996; C = $1997-2012$ )

depicted in a biomass-yield plot (Fig. 6). Relatively high yields were possible on both young fields (e.g. field 20 , in the third vegetation period) as well as old fields (e.g. field 8 with 40 years of land use, see Table 1). The smallest yields (up to $100 \mathrm{~kg}$ per ha) were observed on young fields (age class C, Fig. 6). However, an ANOVA test did not show significant differences of yield between the age classes.

With regard to the boxplots showing yields for the three landscape units (Fig. 7), a reduced yield on acres of the Kalahari Dune Area is indicated; however this group consists only of two fields and is thus not appropriately covered by the assessment. The yields on the Old Floodplain soils are not larger than on the sandy soils of the Transition Zone.

\section{Discussion}

The fact, that cob quality is not correlated with yield showed that an estimation of yield by estimating the condition of cobs is not appropriate but if necessary then a scale of five categories might be sufficient. It seems to be necessary to do direct measurements on the fields with a sampling procedure which is more complex but gives better data. However, the sampling procedure showed that the complexity can result in some inconsistencies and so the sampling procedure has to be as simple as possible.
In spite of the correlation of measured and calculated crops we do not recommend only measuring the dry cobs. Uncertainty might be introduced due to a loss of grains by birds or biomass from unfertile cobs. However, the current data give initial insights in the yields produced by traditional land use technique in the Mashare core site. Comparable data from the literature are scarce. However our findings give comparable yields. For results on a trial in Mashare see Rohrbach et al. (1999). Matanyair (1996) reported grain yields for northern Namibia of 240 $\mathrm{kg} \mathrm{ha}^{-1}$ to $260 \mathrm{~kg} \mathrm{ha}^{-1}$ and $100 \mathrm{~kg} \mathrm{ha}^{-1}$ in drought years. Keyler (1995) gave an estimation of $100-300 \mathrm{~kg} \mathrm{ha}^{-1}$ for the Kavango region, whereas Kolberg (1995) reported grain yields between $100 \mathrm{~kg} \mathrm{ha}^{-1}$ and $900 \mathrm{~kg} \mathrm{ha}^{-1}$ and $1200 \mathrm{~kg} \mathrm{ha}^{-1}$ with improved fertilization and pearl millet varieties for northern Namibia. None of this studies included an empirical assessment, thus a comparison of measured yields in this this study with other empirical data was not possible.

TFO's yield assessment revealed that biomass production is the same over all field age classes as well as over all landscape units. Contrary to the initial assumption that the Old Floodplain soils are more fertile, the data do not show a higher yield in this landscape unit compared to the Kalahari Dune Area and the Transition Zone. This difference may be the result of a lack of precise information of soil conditions on the 


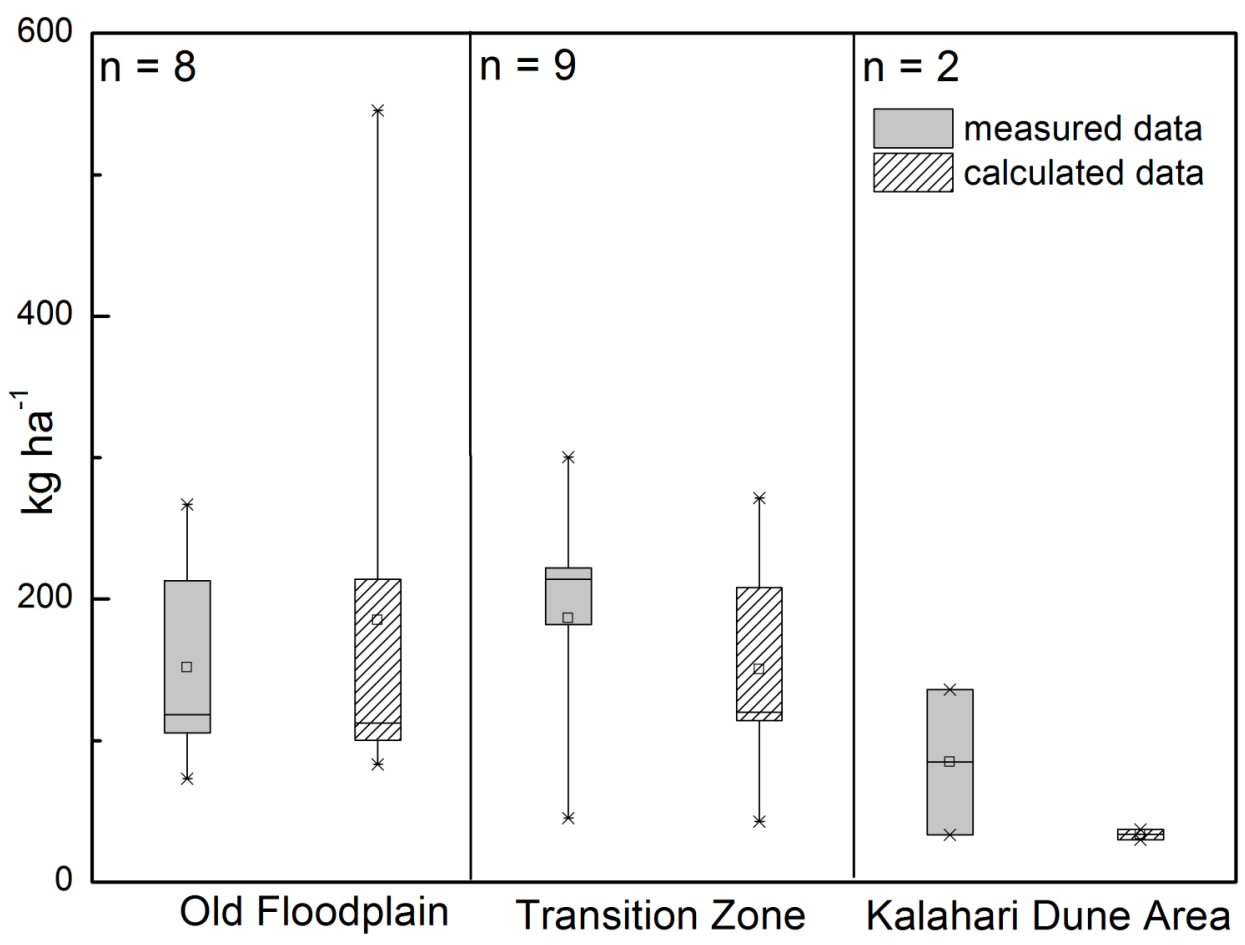

Fig. 7: Boxplots of yield data for landscape units

sampled fields as e.g. parts of the Old Floodplains also contain very sandy and nutrient poor soils on levees (apart from the more nutrient rich and clay soils) (see Groengroeft et al. in press. a). A possible explanation for these unclear correlations may be the high importance of rainfall for agricultural production in the research area, which could not be assessed independently for each sampling area. The Kavango region of Namibia, and thus the Mashare core site, is characterized by an extremely high variability of precipitation both in terms of spatial distribution as well as time (MAWRD 2003, El Obeid \& Mendelsohn 2001). Thus, the influence of rainfall can overshadow all other factors (El Obeid \& Mendelsohn 2001) and lead to the fact that an old field with depleted soils may, due to a more beneficial rainfall distribution, yield a better harvest than a neighboring younger field on better soil which only received a fraction of the needed rainfall. Furthermore, areas of higher soil quality have in most cases been under agricultural land use for many decades. Unsustainable agricultural practices have degraded these areas and led to yields which now are at a low but stable equilibrium (see Vigne \&
Whiteside 1997). Thus, their productive potential may not be higher than that of more recently cleared areas of lower soil quality, e.g. the Kalahari dune sands. However, due to their higher water storage capacity caused by the higher clay content, these soils may still be superior to sandy soils in years of low rainfall and thus be important in terms of food security.

The missing relation between yields and soil fertility may also be explained by some inconsistencies within the data. Therefore we propose that the data should not only be complemented by a second year of assessment but also with some steps of improvement in the sampling procedure. Here the drying and weighing of the material should be improved and the consistency between cob weight and grain weight controlled. Farmers were only able to estimate the amount of crops harvested before TFO's assessment in bags of $50 \mathrm{~kg}$. Therefore, the size of the sample area should also be measured to have an appropriate reference for correctly incorporating the preassessment harvest.

Furthermore, it is of critical importance to thoroughly train the local staff, especially in regards to the interviews that they have to conduct. Only then is it possible to capture all important management differences of a field (e.g. higher soil fertility around homesteads due to application of household waste or on some areas of the field due to previous use as a kraal).

\section{Acknowledgements}

The investigations were founded by a grant of the $\mathrm{BMBF}$ in the project The Future Okavango (01 LL 0912 A). We thank Robert Mukuya and Modestus Kambumburu the field work. Thanks go also to Rasmus Revermann and Manfred Finckh, who were involved in the development of the sampling method. We also thank Annette Eschenbach and Benjamin Runkle for their fruitful recommendations for improving the manuscript.

\section{References}

Boserup, E. (1965): The Conditions of Agricultural Growth: The Economics of Agrarian Change under Population Pressure. Chicago: Aldine. London: Allen \& Unwin. 
Chikuvire, T. J., Mpepereki, S., Foti, R., (2007): Soil fertility variability in sandy soils and implications for nutrient management by Smallholder farmers in Zimbabwe. - Journal of Sustainable Agriculture 30(2): 69-87. CrossRef

Groengroeft, A., Luther-Mosebach, J., Landschreiber, L., Eschenbach, A. (2013): Mashare - Soils. - Biodiversity \& Ecology 5: 105-108. CrossRef

Groengroeft, A., Luther-Mosebach, J., Landschreiber, L., Revermann, R. Finkh, M., Eschenbach A. (2013): Mashare - Landscape. - Biodiversity \& Ecology 5: 101-102. CrossRef

Dumanski, J., Onofrei, C. (1989): Techniques of crop yield assessment for agricultural land evaluation. - Soil Use and Management 5(1): 9-16.

El Obeid, S. \& Mendelsohn, J.M. (2001): A preliminary profile of the Kavango region in Namibia. Namibia Nature Foundation.

Keyler, S. (1995): Economics of the pear millet subsector in northern Namibia: a summary of baseline data. ICRISAT Southern and Eastern Africa Region Working Paper 95/03. PO Box 776, Bulawayo, Zimbabwe: SADC/ICRISAT Sorghum and Millet Improvement Program.

Kolberg, H. (1995): Country Report To The FAO International Technical Conference on Plant Genetic Resources, eds. 5-72. Windhoek: National Plant Genetic Resources Centre.

Kroeger, T., Casey, F. (2007): An assessment of market-based approaches to providing ecosystem services on agricultural lands. Ecological Economics 64(2): 321-332. CrossRef

Landon, J. R. (1991). Booker Tropical Soil Manual - A Handbook for soil survey and agricultural land evaluation in the tropics and subtropics. London: Booker Agriculture International Ltd.

Matanyair, C.M. (1996): Pearl Millet Production System(s) in the Communal Areas of Northern Namibia: Priority Research Foci Arising from a Diagnostic Study. In Drought-tolerant crops for southern Africa: proceedings of the SADC/ICRISAT Regional Sorghum and Pearl Millet Workshop, 25-29 Jul 1994, [Eds.] K. Leuschner and C. S. Manthe. 43-58. Gaborone: International Crops Research Institute for Semi-Arid Topics.

Matlon, P.J. (1990): Improving productivity in sorghum and pearl millet in semi-arid Africa. - Food Research Institute Studies 22(1): 1-43.

MAWRD (Namibian Ministry of Agriculture, Water and Rural Development) (2003): Baseline survey of the impact of agricultural extension services in Kavango region. Directorate of Extension and Engenrring services, Rundu.

Mendelsohn, J., El Obeid, S. (2004):
Okavango River - The flow of a lifeline. Windhoek: Struik Publishers \& Raison

Mendelsohn, J. (2006): Farming systems in Namibia. Windhoek: Raison

Quinn, G.P. \& Keough, M.J. (2002): Experimental design and data analysis for biologists. Cambridge University Press, Cambridge, UK. CrossRef

Rohrbach, D.D., W.R Lechner, S.A. Ipinge, and E.S. Monyo. (1999): Impact from investments in crop breeding: the case of Okashana 1 in Namibia. In Impact Series. 48pp. Patancheru: International Crops Research Institute for the SemiArid Tropics.

de Cauwer, V. (2013): Mashare Vegetation. - Biodiversity \& Ecology 5: 117-119.

Ruthenberg, H. (1971): Farming Systems in the Tropics. Clandon Press. Oxford.

Stein, A., J. Brouwer, and J. Bouma. (1997): Methods for comparing spatial variability patterns of millet yield and soil data. - Soil Science Society of America Journal 61(3): 861-870. CrossRef

Vigne, P. \& Whiteside, M. (1997). Encouraging sustainable smallholder agriculture in Namibia. Agricultural Services Reform in Southern Africa. Phase 2 - Working Papers. Environment and Development Consultancy Ltd., UK.

Weber, T. (2013): Mashare - Climate. Biodiversity \& Ecology 5: 103-104. CrossRef

\section{Affiliations}

Alexander Groengroeft

(a.groengroeft@ifb.uni-hamburg.de),

Jona Luther-Mosebach* (jona.luther-

mosebach@uni-hamburg.de), Lars

Landschreiber (lars.landschreiber@uni-

hamburg.de)

Institute of Soil Science

University of Hamburg

20146 Hamburg, GERMANY

Benjamin Kowalski

(benjamin.kowalski@agrar.uni-

giessen.de)

Institute of Agricultural Policy and

Market Research

University of Giessen

35390 Giessen, GERMANY

*Corresponding author 